\title{
THE SHARE OF AGRICULTURE IN GREENHOUSE GAS EMISSIONS IN EUROPEAN UNION COUNTRIES - VALUATION
}

Konrad PRANDECKI, Institute of Agricultural and Food Economics - National Research Institute (IAFE), General Economics Department, Świętokrzyska 20,00-002 Warszawa, Poland, konrad.prandecki@ierigz.waw.pl (corresponding author) Edyta GAJOS, Institute of Agricultural and Food Economics - National Research Institute (IAFE), General Economics Department, Świętokrzyska 20, 00-002 Warszawa, Poland, edyta.gajos@ierigz.waw.p 1

Reducing greenhouse gases emissions is one of the major environmental challenges of the modern world. The European Union (EU) has set itself ambitious reduction targets. Proper monitoring of emissions and its valuation is necessary to achieve this goal. In addition, valuation (in monetary terms) will help to raise awareness of the climate change costs among society.

The aim of this article is to present international comparisons within the EU covering the monitoring and valuation of aggregate emissions of selected greenhouse gases in general and in agriculture. The study uses Eurostat data for the years 2007-2015. The evaluation was based on the average annual price of carbon dioxide allowances under the European Union Emissions Trading System. Leipzig stock market data were used to determine the price.

The study compares the total greenhouse gas emissions and its value in different EU countries. These results show that the largest emitters in the EU are Germany, United Kingdom, France. A comparison of per capita and per GDP emissions results in an almost reversal of this order. The share of agriculture in greenhouse gas emissions was $11 \%$ in 2015 and ranged between countries from $3 \%$ (Malta) do 32\% (Ireland). The results show also that the decline in value is greater than the decrease in emissions. This is due to the dramatic change in the price of allowances. The decrease in quantity of agricultural emission was $0,5 \%$, whilst the decrease in value was $55,5 \%$ between years 2008 and 2015 .

Keywords: agriculture, country comparison, European Union, externalities, greenhouse gases emission valuation

\section{INTRODUCTION}

The effects of climate change are one of major threats to the sustainability of the human civilisation. The scale of this change is difficult to estimate in detail, but even general studies on this issue point to a possibility for significant adverse effects to occur. This is described in most detail in the periodical reports of the International Panel on Climate Change - IPCC (cf. IPCC, 2013, 2014).

In order to prevent climate change, various countries shall take their own initiatives aimed at reducing greenhouse gas (GHG) emissions. In many cases, these actions are virtual due to high costs and the absence of unequivocal effects. Even in the developed countries, for example in the U.S., where the awareness of risks associated with climate change should be higher, many initiatives are partial, i.e. they do not resolve the problem comprehensively.

The European Union (EU) has adopted the objective to lead the world efforts in counteracting climate change. The implementation of such an ambitious objective entails a need to reduce emissions in physical terms. One of the tools used to achieve the reduction objective is the European Union Emission Trading System - EU ETS (EU, 2014). The actions are taken gradually, i.e. the number of economic sectors obliged for such a reduction is gradually increased and the increasing restrictions are introduced. The objectives in this area have been specified until mid-21th century (EC, 2011).

Apart from the general objective for the given sector, which is intended to be achieved by all Member States, the EU's climate policy is based on the national objectives. They are, to a certain extent, adapted to the reduction potential of the countries, but, actually, in terms of the technical and financial capacity, rather than of social costs of such action. When we reflect more deeply on the issue of the climate policy, it seems reasonable for it to include also the indicators illustrating emissions in relation to the economy, size of the country or its population. Making the country reduce emissions coming from the sectors essential to its security, for example, the food sector, is deeply unfounded. Of course, we should strive for reducing emissions, but maybe in this case more advisable would be other solutions available along with the development of technical progress or alternative solutions, for example, increased absorption of substances in the air. Owing to these doubts, it is necessary to examine which EU countries are more and which are less effective in terms of GHG emissions and to determine whether this will allow to develop the recommendations for the climate policy.

Physical reduction of GHG or increase of its absorption are the only effective solutions to the climate change problem. However to obtain this goal public awareness and proper policy is needed. There are numerous publications on measuring

Copyright (C) 2017 The Authors. Published by Aleksandras Stulginskis University. This is an open-access article distributed under the terms of the Creative Commons Attribution License (CC-BY 4.0), which permits unrestricted use, distribution, and reproduction in any medium, provided the original author and source are credited. 
GHGs emissions in agriculture (Bennetzen et al., 2016; Bell et al., 2014; IPCC, 2013) and policies which should be implemented (Jones, Jones, Cross, 2015, Yue et al., 2017). The increase of public awareness is possible, among others, due to the valuation of GHG. The value expressed in monetary terms is the best way to inform society about mischievousness of GHGs. However GHG belongs to externalities, which means there is no direct cost analysis of its emission. Only indirect methods are available (Adaman et al., 2011; Isacs, 2016; Dequiedt and Moran, 2015; Vermont and De Cara, 2010).

The objective of this paper is to present international comparisons within the EU covering the monitoring and valuation of aggregate emissions of selected GHGs in total and in agriculture. This is not the complete valuation, as the presented method ignores a range of losses caused by these chemical compounds and does not take into account remedial costs. However, the resulting valuation makes it possible to compare the costs of emissions among the sectors and also internationally.

\section{METHODOLOGY}

The paper uses the Eurostat data on GHG emissions in the EU countries and selected characteristics of these countries (gross domestic product per country and per economy sector and country population) for the years 2007-2015. The simple statistical data processing methods have been used and the results have been presented in a form of tables. The valuation of emissions has been carried out using the market valuation method developed by the authors (the method is described in more detail in (Prandecki, Gajos, 2017)). The process started with standardisation of emissions units by converting them to carbon dioxide equivalent (with exception of substances already presented by Eurostat in carbon dioxide equivalent, like HFCs gases). It was done using the Global Warming Potential indicators for each substance. This way the results obtained are based on the harmfulness of emissions. The second step was to valuate emissions. The purchase price of emission rights from the EU ETS was used. Due to that the calculation takes into account the actual economic value of 1 tonne of carbon dioxide emission. Therefore the valuation not only illustrate the changes to physical volume of emissions but also economic changes on the market (price fluctuations due to supply and demand of carbon dioxide emission rights). Prices of emission rights comes from the European Energy Exchange (EEX) market based in Leipzig, Germany (quotations available on cire.pl). This exchange has been selected due to the fact that it functioned both during the second and the current third trading period of EU ETS, and thus the entire period covered by this study. Daily quotations was obtained and than the annual average price of emission of 1 tonne of carbon dioxide was calculated as an arithmetic mean of daily prices of emission rights. The final step was to valuate GHG emission using emission data and annual allowance price.

\section{RESULTS}

Greenhouse gas emissions in the EU countries are decreasing in the analysed period. The overall decrease in emissions in 2015 amounted to 16.3\% when compared to 2007 (4308,0 million tones in comparison to 5149,6 million tones). The countries emitting the highest amounts of GHGs in absolute terms are Germany, Great Britain, France and Italy. Each of these countries emitted in 2015 more than 400 million tonnes of carbon dioxide equivalent. In turn, Malta, Cyprus and Luxembourg are the countries with the lowest emissions (10 and less million tonnes of emissions). The range in the amounts of emitted GHGs is therefore enormous. Germany emits more than 400 times more GHG than Malta. We should, of course, bear in mind that these differences to some extent result from the size of the countries, however, the nature of the economy is also very important. The economy based on heavy industry emits more pollutants than that based on the so-called clean sectors. This is shown excellently when we compare Germany and Sweden. Although Sweden is bigger in size, its GHG emissions are 17 times lower than those in Germany.

The rate of reducing GHG emissions is also very diversified. In general, in the EU in the period of 2007-2015 the decrease was $16.3 \%$. In the individual countries, the changes range from the decrease by about $30 \%$ (Denmark, Malta, Finland, Greece) to the decrease by about 6-7\% (the Netherlands, Poland, Germany). It is worth noting that there is no correlation between the size of emissions in physical units and the rate of reduction. In the case of Germany or Poland (countries with high emissions), the decreases were below 8\%, while, for example, Malta and Finland reduced their emissions by about $30 \%$. There are also, of course, the examples of the countries which effectively reduce their high emissions, for example, Great Britain (decrease by $25.1 \%$ ).

The reference of the amount of emissions to GDP makes it possible to compare the individual countries, taking into account the size of their economy. In this case, the countries whose economies have the highest emission load are Bulgaria, Poland and Estonia. Germany is placed 16th in this ranking. The countries with the lowest emissions per GDP are Sweden, Denmark and Great Britain. These are the countries whose economies are environmentally efficient. Great Britain is one of the countries emitting the highest total amounts of GHGs, however, the reference of the amount of emissions to the size of the economy shows that, despite significant absolute emissions, the country is relatively less harmful from the analysed point of view than the majority of other Community countries. It is also worth noting that in the entire EU, the emission load on the economy decreased by $26.4 \%$. To the greatest extent, the situation improved in Malta, Luxembourg and Denmark.

The last indicator discussed in this part is the amount of emissions per capita. The highest values of this indicator are in Luxembourg, Estonia and Ireland, the lowest - in Malta, Sweden and Croatia. Again, Sweden turned out to be an environmentally efficient country. Just like in the case of the previous characteristics, the situation improved in the analysed period - the amount of emissions per 1 thousand residents in the EU decreased by 18.0\%. Denmark, Malta and Finland are the countries where the emission load on the residents decreased most.

The presented indicators clearly show that the actions taken by the EU to reduce GHG emissions bring positive effects. Total emissions were reduced significantly in the discussed period while with reference to the size of the economy or the population 
the situation improved even more. The diverse values of the indicators and the rate of their changes suggest that the Member States handle the reduction objectives differently and also point to a need to monitor the situation. The leaders are undoubtedly Malta and Denmark, which to the greatest extent improved the emission load in the analysed period for both analysed criteria.

Table 1 presents data on the amounts of agricultural GHG emissions in the EU countries in total and per GDP as well as the share of agriculture in total emissions in the selected years from the period 2007-2015. Agricultural emissions in 2015 were more than 436 million tonnes of carbon dioxide equivalent, which gave that sector the share of $10 \%$. The situation in each country is very diverse. Agriculture in Malta is responsible for $3.0 \%$ of country emissions, while in Ireland this share is as high as $32.1 \%$. The share of agriculture in GHG emissions in the EU increased in the analysed period by 1.5 percentage points despite the decrease in emissions by about $0.5 \%$. This is a trend occurring in all Community countries. In Latvia, Denmark or Ireland, the share of agriculture in total emissions increased by 5-6\%. This fact, combined with the decrease in total emissions in the EU by $16.3 \%$ indicates that the rate of emission reduction in other sectors of the economy was faster in the analysed period. In particular, this applies to the reduction efforts undertaken in the economic sectors covered by the EU ETS mechanism which have been taking those efforts intensely for many years. In the sectors such as agriculture, the existing regulations have been much lenient.

Table 1. Amount of greenhouse gas emissions by agriculture in the European Union countries in total, per GDP and the share of agriculture in emissions in total

\begin{tabular}{|c|c|c|c|c|c|c|c|c|c|c|c|c|}
\hline \multirow{2}{*}{ Country/Year } & \multicolumn{3}{|c|}{2007} & \multicolumn{3}{|c|}{2009} & \multicolumn{3}{|c|}{2012} & \multicolumn{3}{|c|}{2015} \\
\hline & 1 & 2 & 3 & 1 & 2 & 3 & 1 & 2 & 3 & 1 & 2 & 3 \\
\hline European Union & 439,1 & 33,8 & $8,5 \%$ & 431,2 & 35,1 & $9,2 \%$ & 423,8 & 31,5 & $10,3 \%$ & 436,7 & 29,6 & $10,1 \%$ \\
\hline Austria & 7,1 & 25,1 & $8,2 \%$ & 7,2 & 25,2 & $9,0 \%$ & 7,1 & 22,2 & $8,8 \%$ & 7,2 & 20,8 & $9,1 \%$ \\
\hline Belgium & 10,3 & 29,8 & $7,4 \%$ & 10,3 & 29,5 & $8,2 \%$ & 9,9 & 25,6 & $8,3 \%$ & 10,0 & 24,4 & $8,5 \%$ \\
\hline Bulgaria & 4,7 & 144,9 & $6,9 \%$ & 4,8 & 127,9 & $8,3 \%$ & 5,0 & 119,6 & $8,3 \%$ & 5,9 & 131,1 & $9,7 \%$ \\
\hline Croatia & 2,9 & 66,5 & $9,4 \%$ & 2,8 & 62,0 & $10,0 \%$ & 2,7 & 61,6 & $10,8 \%$ & 2,6 & 58,0 & $10,9 \%$ \\
\hline Cyprus & 0,6 & 36,6 & $6,5 \%$ & 0,6 & 32,8 & $6,2 \%$ & 0,6 & 30,5 & $6,8 \%$ & 0,6 & 31,7 & $6,6 \%$ \\
\hline Czech Republic & 8,3 & 59,8 & $5,5 \%$ & 7,9 & 53,3 & $5,8 \%$ & 7,9 & 48,9 & $5,9 \%$ & 8,5 & 50,4 & $6,7 \%$ \\
\hline Denmark & 10,8 & 46,1 & $15,6 \%$ & 10,4 & 45,0 & $16,7 \%$ & 10,3 & 40,4 & $19,5 \%$ & 10,3 & 37,9 & $21,5 \%$ \\
\hline Estonia & 1,2 & 72,6 & $5,3 \%$ & 1,2 & 82,9 & $7,0 \%$ & 1,3 & 72,9 & $6,5 \%$ & 1,3 & 65,7 & $7,4 \%$ \\
\hline Finland & 6,4 & 34,3 & $8,1 \%$ & 6,5 & 35,8 & $9,6 \%$ & 6,4 & 31,9 & $10,2 \%$ & 6,5 & 30,9 & $11,7 \%$ \\
\hline France & 79,5 & 40,9 & $15,0 \%$ & 79,2 & 40,8 & $15,7 \%$ & 77,1 & 36,9 & $15,9 \%$ & 78,4 & 35,7 & $17,1 \%$ \\
\hline Germany & 62,0 & 24,7 & $6,4 \%$ & 63,7 & 25,9 & $7,0 \%$ & 64,1 & 23,2 & $6,9 \%$ & 67,0 & 22,0 & $7,4 \%$ \\
\hline Greece & 9,0 & 38,6 & $6,6 \%$ & 8,5 & 35,8 & $6,8 \%$ & 8,4 & 44,2 & $7,5 \%$ & 8,3 & 47,3 & $8,7 \%$ \\
\hline Hungary & 6,1 & 59,5 & $8,3 \%$ & 5,7 & 61,0 & $8,8 \%$ & 5,9 & 60,0 & $9,9 \%$ & 6,7 & 60,9 & $10,9 \%$ \\
\hline Ireland & 18,6 & 94,5 & $27,2 \%$ & 18,3 & 107,5 & $29,4 \%$ & 18,1 & 103,1 & $31,1 \%$ & 19,2 & 73,4 & $32,1 \%$ \\
\hline Italy & 33,0 & 20,5 & $5,9 \%$ & 31,3 & 19,9 & $6,3 \%$ & 31,5 & 19,5 & $6,7 \%$ & 30,0 & 18,1 & $6,9 \%$ \\
\hline Latvia & 2,3 & 103,5 & $19,1 \%$ & 2,4 & 125,5 & $21,2 \%$ & 2,5 & 113,6 & $22,1 \%$ & 2,7 & 112,4 & $24,2 \%$ \\
\hline Lithuania & 4,5 & 154,6 & $17,6 \%$ & 4,4 & 162,7 & $21,9 \%$ & 4,4 & 131,3 & $20,6 \%$ & 4,6 & 123,2 & $22,9 \%$ \\
\hline Luxembourg & 0,6 & 17,3 & $5,2 \%$ & 0,7 & 17,8 & $5,7 \%$ & 0,6 & 14,6 & $5,5 \%$ & 0,7 & 13,0 & $6,6 \%$ \\
\hline Malta & 0,1 & 13,1 & $2,4 \%$ & 0,1 & 11,5 & $2,4 \%$ & 0,1 & 9,4 & $2,1 \%$ & 0,1 & 7,1 & $3,0 \%$ \\
\hline Netherlands & 18,6 & 30,3 & $8,9 \%$ & 18,5 & 29,9 & $9,1 \%$ & 18,0 & 27,9 & $9,2 \%$ & 19,2 & 28,1 & $9,8 \%$ \\
\hline Poland & 30,9 & 98,3 & $7,5 \%$ & 30,2 & 95,3 & $7,8 \%$ & 30,0 & 76,9 & $7,5 \%$ & 29,6 & 68,9 & $7,7 \%$ \\
\hline Portugal & 6,7 & 38,1 & $8,4 \%$ & 6,5 & 37,3 & $8,9 \%$ & 6,5 & 38,5 & $9,8 \%$ & 6,6 & 36,8 & $9,6 \%$ \\
\hline Romania & 20,6 & 164,4 & $13,7 \%$ & 19,6 & 162,8 & $15,5 \%$ & 17,6 & 132,0 & $14,2 \%$ & 18,6 & 116,4 & $16,0 \%$ \\
\hline Slovakia & 3,0 & 53,6 & $6,1 \%$ & 2,8 & 43,7 & $6,1 \%$ & 2,9 & 39,8 & $6,7 \%$ & 3,0 & 38,3 & $7,3 \%$ \\
\hline Slovenia & 1,8 & 51,9 & $8,8 \%$ & 1,8 & 48,5 & $9,0 \%$ & 1,7 & 46,5 & $8,8 \%$ & 1,7 & 44,9 & $10,4 \%$ \\
\hline Spain & 37,8 & 35,0 & $8,6 \%$ & 35,4 & 32,8 & $9,6 \%$ & 33,1 & 31,8 & $9,4 \%$ & 36,0 & 33,3 & $10,7 \%$ \\
\hline Sweden & 6,9 & 19,3 & $10,5 \%$ & 6,7 & 21,7 & $11,5 \%$ & 6,7 & 15,8 & $11,7 \%$ & 6,9 & 15,4 & $12,8 \%$ \\
\hline United Kingdom & 44,9 & 20,1 & $6,7 \%$ & 43,8 & 25,7 & $7,4 \%$ & 43,5 & 21,1 & $7,5 \%$ & 44,6 & 17,3 & $8,9 \%$ \\
\hline
\end{tabular}

1. Amount of emissions in million tonnes.

2. Amount of emissions per GDP in thousand tonnes/EUR 1 million.

3. Share of agriculture in emissions of the countries in total.

Source: own study based on Eurostat. 
It is worth noting that in recent years of the analysis there has been an increase in agricultural emissions. This situation is very unfavourable from the emission reduction policy's point of view. Based on the available data, we cannot conclude clearly whether this is a permanent reversal of the trend or just a several-years anomaly.

The above information makes us take a deeper reflection on the sources of agricultural emissions and reasons for the increases, as it may turn out that at the current technical level the effective emission reduction without changing the production structure or decreasing the production scale is not possible. This means that the planned emission reduction in the agricultural sector may lead to the increased risk for food security. This statement, although not unfounded, requires further in-depth analyses of sources of agricultural GHG emissions in the context of food security, productivity and profitability of agriculture.

Most agricultural GHGs are emitted by France, Germany, Great Britain, Spain and Italy. This means that there is a correlation between the amount of total emissions in a given country and the amount of agricultural emissions. Four of the five countries with the largest total emissions are also the countries whose agriculture emits the highest amounts of GHGs in the EU. These are the countries where predominant agriculture is commonly perceived as industrial and intensive. The low amount of emissions is encountered in the countries with more extensive agriculture. Therefore, from the climate point of view extensive agriculture is the desirable one. On the other hand it is not advisable to encourage this type of farming on the large scale because of the food security in the EU. Thus, authors propose to encourage development of the sustainable agriculture, which takes into account environmental factors as well as food demands.

Table 2. Value of emissions in the European Union countries in total and per GDP and per capita

\begin{tabular}{|c|c|c|c|c|c|c|c|c|c|c|}
\hline \multirow{2}{*}{ Country/Year } & \multicolumn{2}{|c|}{2008} & \multicolumn{2}{|c|}{2012} & \multicolumn{2}{|c|}{2015} & \multicolumn{2}{|c|}{2015 per GDP } & \multicolumn{2}{|c|}{2015 per capita } \\
\hline & General & Agr. & General & Agr. & General & Agr. & General & Agr. & General & Agr. \\
\hline Unit of measure & \multicolumn{6}{|c|}{ milion euro } & \multicolumn{2}{|c|}{ euro/1 milion euro } & \multicolumn{2}{|c|}{ euro/1 thousand people } \\
\hline European Union & 86804,04 & 7524,57 & 33641,73 & 3128,09 & 33057,21 & 3351,39 & 2240,47 & 227,14 & 65008,71 & 6590,68 \\
\hline Austria & 1498,64 & 124,58 & 590,82 & 52,24 & 605,06 & 55,00 & 1756,38 & 159,67 & 70550,79 & 6413,47 \\
\hline Belgium & 2392,95 & 174,64 & 878,44 & 73,16 & 901,20 & 76,76 & 2196,73 & 187,10 & 80197,50 & 6830,52 \\
\hline Bulgaria & 1150,66 & 85,38 & 446,71 & 37,04 & 471,79 & 45,56 & 10417,85 & 1006,12 & 65506,13 & 6326,36 \\
\hline Croatia & 515,28 & 50,16 & 185,44 & 19,97 & 180,34 & 19,61 & 4092,40 & 444,95 & 42681,74 & 4640,66 \\
\hline Cyprus & 173,99 & 10,63 & 64,72 & 4,38 & 64,69 & 4,29 & 3667,93 & 243,34 & 76377,19 & 5067,00 \\
\hline Czech Republic & 2502,28 & 144,53 & 985,92 & 58,29 & 975,51 & 65,09 & 5790,28 & 386,38 & 92568,11 & 6176,94 \\
\hline Denmark & 1123,54 & 184,37 & 388,75 & 75,84 & 367,70 & 79,03 & 1352,92 & 290,77 & 64968,63 & 13962,98 \\
\hline Estonia & 344,79 & 21,31 & 148,51 & 9,65 & 138,43 & 10,26 & 6803,41 & 504,44 & 105283,18 & 7806,27 \\
\hline Finland & 1225,70 & 111,54 & 460,11 & 47,05 & 425,93 & 49,73 & 2032,32 & 237,29 & 77842,47 & 9088,81 \\
\hline France & 9039,59 & 1379,09 & 3568,60 & 568,83 & 3507,78 & 601,40 & 1598,63 & 274,08 & 52757,91 & 9045,14 \\
\hline Germany & 16804,49 & 1109,08 & 6841,81 & 473,00 & 6920,97 & 513,78 & 2273,91 & 168,80 & 85236,27 & 6327,54 \\
\hline Greece & 2270,19 & 150,26 & 826,94 & 62,35 & 734,47 & 63,77 & 4180,31 & 362,93 & 67643,12 & 5872,76 \\
\hline Hungary & 1224,79 & 104,71 & 443,95 & 43,89 & 468,79 & 51,23 & 4274,37 & 467,12 & 47565,77 & 5198,18 \\
\hline Ireland & 1170,37 & 318,35 & 429,06 & 133,57 & 459,48 & 147,54 & 1753,47 & 563,05 & 99261,34 & 31873,18 \\
\hline Italy & 9451,39 & 551,56 & 3470,49 & 232,20 & 3322,82 & 229,85 & 2011,20 & 139,12 & 54655,52 & 3780,66 \\
\hline Latvia & 203,47 & 40,10 & 83,65 & 18,50 & 86,73 & 21,02 & 3559,18 & 862,70 & 43669,13 & 10584,91 \\
\hline Lithuania & 421,09 & 74,83 & 156,70 & 32,33 & 154,21 & 35,30 & 4130,89 & 945,62 & 52788,26 & 12083,96 \\
\hline Luxembourg & 208,82 & 11,30 & 86,73 & 4,74 & 78,80 & 5,22 & 1505,52 & 99,82 & 139972,56 & 9280,18 \\
\hline Malta & 53,48 & 1,25 & 23,87 & 0,50 & 17,09 & 0,51 & 1842,46 & 54,52 & 39800,01 & 1177,81 \\
\hline Netherlands & 3580,28 & 321,03 & 1441,04 & 132,65 & 1496,63 & 147,41 & 2189,79 & 215,68 & 88554,17 & 8722,11 \\
\hline Poland & 7005,91 & 533,23 & 2945,87 & 221,13 & 2960,77 & 227,52 & 6884,90 & 529,07 & 77903,41 & 5986,45 \\
\hline Portugal & 1318,99 & 114,31 & 488,96 & 47,84 & 527,48 & 50,83 & 2933,57 & 282,66 & 50842,60 & 4898,95 \\
\hline Romania & 2514,24 & 349,33 & 918,43 & 130,09 & 893,40 & 142,83 & 5585,02 & 892,87 & 44960,84 & 7187,85 \\
\hline Slovakia & 865,15 & 50,08 & 319,27 & 21,34 & 316,68 & 23,13 & 4024,64 & 293,97 & 58413,80 & 4266,74 \\
\hline Slovenia & 370,65 & 29,99 & 140,55 & 12,40 & 129,15 & 13,38 & 3325,57 & 344,49 & 62608,75 & 6485,53 \\
\hline Spain & 7029,05 & 599,78 & 2597,04 & 244,44 & 2575,70 & 276,08 & 2384,91 & 255,63 & 55451,54 & 5943,69 \\
\hline Sweden & 1083,80 & 120,14 & 421,96 & 49,31 & 411,99 & 52,91 & 917,55 & 117,83 & 42267,18 & 5427,76 \\
\hline United Kingdom & 11260,47 & 759,02 & 4287,36 & 321,36 & 3863,61 & 342,36 & 1497,48 & 132,69 & 59554,47 & 5277,15 \\
\hline
\end{tabular}


Equally important as the amount of emissions is the rate of emission reduction over time. In the examined period, agricultural emissions in the EU has decreased by $0.5 \%$. In the individual countries, these changes are very diversified. In the half of the countries, agricultural GHG emissions increased in the analysed period. In three countries: Bulgaria, Latvia and Estonia, this increase was very high and amounted to a dozen or so percent, and in the case of Bulgaria it was as much as $26.4 \%$. In other countries from this group, the increase in emissions was much lower. In the case of the countries where agricultural GHG emissions decreased in the analysed period, the greatest decrease was recorded in the case of Cyprus (-13.1\%), Malta (-12.3\%) and Romania (-9.7\%).

With regard to the load of agricultural GHG emissions on the economy, the biggest values of this indicator are recorded in Bulgaria, Lithuania and Romania, while the lowest - in Malta, Luxembourg and Sweden. The high load indicator indicates that agricultural GHG emissions have a significant effect on the economy of a given country. In combination with the data on the share of agricultural emissions in total emissions, this gives a certain general picture of the emission situation of the sector and its reduction potential.

Data on the value of GHG emissions in the EU countries and in agriculture is shown in Table 2. There is no change in the ranking of the countries in terms of the value of emissions, both total and agricultural, when compared to the similar rankings calculated based on the amount of emissions. Due to the fact that in a given year the value of emissions was calculated using the same allowance price for all countries, their interrelations have remained unchanged. For this reason, this aspect of analysis will be ignored. The analysis will also ignore the year 2007 as it is a typical outlier in this particular set. The value of emissions in this year is disproportionately low when compared to the values from other years. This situation results from the situation in the allowance market. The average annual allowance price in the EU ETS system is calculated based on the daily quotations on the EEX stock exchange in Leipzig. By analysing these quotations, we may observe that from the beginning of 2007 that price kept on decreasing from EUR 5.53/tonne to EUR 0.02/tonne and remained below EUR 0.5/tonne for a period of 11 months, until March 2008. Then, there was a sharp rise in the price to the level of more than EUR 21/tonne. As a result, the average annual allowance price in 2007 amounted to EUR 0.66/tonne, and in the following year it was already EUR 17.24/tonne. These significant changes in the allowance price are responsible for the values in 2007 which are non-typical of the entire analysed period.

In the analysed period, we can observe a clear downward trend in the values of emissions, both total and agricultural, which results mainly from the decreased carbon dioxide allowance price in the EU ETS system. In the period 2008-2015, the value of emissions in the European Union decreased by $61.9 \%$ and in agriculture by $55.5 \%$. This results mainly from a significant decrease in the allowance prices in the EU ETS system (from EUR 17.24/tonne to EUR 7.67/tonne).

Interesting are the possibilities to analyse the costs of emissions per GDP and per capita. Such analysis can be made in a point of time. The comparison over time is encumbered by excessive changes resulting from fluctuations in allowance prices, which in the analysed period were higher than the physical changes in emissions of analysed substances into the air. On average, in the EU in 2015 every EUR 1 million of GDP was charged with the costs of emissions of more than EUR 2,200, while the cost from agriculture was EUR 227. In per capita terms, each thousand of residents incurred the costs of more than EUR 65,000 while the costs associated with agricultural emissions were almost EUR 6,600. Using these values, although calculated in an imperfect way, we can more easily make the public aware of the harmfulness of careless emissions, rather than using complex indicators. A comparison of these average values with the results for the individual Member States allows us to realise the load of emissions in the given country. It is worth remembering that the higher is the value of the indicator, the higher is the environmental cost. For this reason, a comparison of the situation in the agricultural sector leads to a conclusion that the economies with the highest load of agricultural emissions are those of Bulgaria, Lithuania and Romania. In turn, the least loaded are Malta, Luxembourg and Sweden.

The indicator of the value of per capita emissions allows us to realise the amount per each citizen. The assessment of the data in the table does not allow to draw up even general conclusions, i.e. there is no regularity in the value of the indicator and the size of the country.

\section{CONCLUSIONS}

Typical GHGs reduction policy is based on single criteria, mostly emission per country. Such attitude is very simple and does not show the complexity of climate mitigation problems. In our opinion multicriteria analysis is much better. We suggest a three dimensional analysis with approach similar to sustainable development. The first measure is environmental - GHG emission per country, the second is economic - GHG emission per GDP, the third is social one GHG emission per capita. The first measure shows the need of reduction, but it does not include the size of the country nor its economy. That is why we noticed the need to a more complex analysis.

The efficiency of emissions per GDP shows the amount of pollutants or their value per national income unit. Such an analysis can be carried out both in the context of the country and of the sector. It allows to indicate whether the given country and sector are effective when compared to other similar entities. The results of such comparison may be confronted with the share of the sector in total emissions, which allows to assess whether or not the country's load for the economy is bigger than it results from its share in total emissions. It is especially important in the case of agriculture where national standards are in use, not EU ETS mechanism.

The third measure - emissions per capita often reverses the rankings of the countries with the highest emissions. The same applies to the EU countries. For example France is the third GHG emitter in EU, but its emission per capita is low. The country is in the group of nine countries with lowest emission in the EU.

Only such complex, multicriteria analysis and comparison of countries or its economic sectors can give fair results. However such analysis is much more complicated, and the results are not always so obvious as in case of simple 
comparison of emission per country. For example using only single measure analysis we can observe that emission in countries using intensive agriculture is bigger than in extensive one. However when we apply additional measure it may appear that country with intensive farming has much more inhabitants and is more effective in terms of emission per capita. In this case intensity can be justified by social needs.

Obtained results show a large diversity of GHG emissions from the EU Member States. The specificities of the economies are so strong that comparing emissions based on various sets of indicators does not lead to any generalisation in terms of the climate policy and does not show any clear trend. High emissions may occur in small, big, poor or rich countries. It is difficult to indicate one universal formula to solve the climate issues. Instead of observing trends, the presented method may be useful for comparison between countries, especially when one has to decide about climate policy goals, e.g. within EU. For example our multicriteria analysis show that only Poland is a very high emitter in all three criteria. That means that it has to pay more attention to the climate policy than other EU members.

The presented overall data for the European Union Member States shows that the amount of emissions for the EU gradually decreases in the analysed period, which is a desirable phenomenon. It should also be stressed that the reduction took place in all Member States, although its rate was diversified.

The situation in agriculture is not so obvious as in the last years of the analysed period in some countries emissions increased. This can lead to a conclusion on a large difficulty in emission reductions in this sector, and even to the increase risk of losing food security where meeting the reduction commitments expected in the years 2020-2030 entails the reduced production scale.

The GHG emission reduction is carried out based on physical units, which is reasonable from the point of view of achieving the determined reduction objectives. However, providing the data to the public in such a way does not always result in the increased public awareness. For this reason, financial data is much more likely to reach the public consciousness. In addition, valuation of emissions is an effective method of comparison different sectors.

The presented emission valuation mechanism is based on the market carbon dioxide allowance prices in the EU ETS system from the Leipzig stock exchange. Just like each stock exchange valuation, it is characterised by high volatility, which is unfavourable where emissions are valued as an externality, as the physical values related to externalities are usually not as variable as their monetary valuation. Due to this, the used method of valuation is more advisable in case of the analysis in a particular point of time.

\section{REFERENCES}

1. Adaman, F., Karali, N., Kumbaroğlu, G., Or İ., Özkaynak, B., Zenginobuz, Ü. 2011. What determines urban households' willingness to pay for CO2 emission reductions in Turkey: a contingent valuation survey. Energy Policy, Vol. 39, pp. 689-698. https://doi.org/10.1016/j.enpol.2010.10.042

2. Bell, M.J., Cloy, J.M., Rees, R.M. 2014. The true extent of agriculture's contribution to national greenhouse gas emissions. Environmental Science \& Policy, Vol. 39, pp. 1-12. https://doi.org/10.1016/j.envsci.2014.02.001

3. Bennetzen, E.H., Smith, P., Porter, J.R. 2016. Agricultural production and greenhouse gas emissions from world regions--The major trends over 40 years. Global Environmental Change, Vol. 37, pp. 43-55. https://doi.org/10.1016/j.gloenvcha.2015.12.004

4. cire.pl http://www.handel-emisjami-co2.cire.pl/. (Accessed on 18/10/2017)

5. Dequiedt, B., Moran, D., 2015. The cost of emission mitigation by legume crops in French agriculture. Ecological Economics , Vol. 110, pp. 51-60. https://doi.org/10.1016/j.ecolecon.2014.12.006

6. EC. 2011. A Roadmap for moving to a competitive low carbon economy in 2050. COM(2011) 112 final. Brussels: European Commission.

7. EU. 2014. Regulation (EU) No 421/2014 of the European Parliament and of the Council of 16 April 2014 amending Directive 2003/87/EC establishing a scheme for greenhouse gas emission allowance trading within the Community, in view of the implementation by 2020 of an international agreement applying a single global market-based measure to international aviation emissions Text with EEA relevance. OJ L 129, 30.4.2014, p. 1-4.

8. Eurostat http://ec.europa.eu/eurostat. (Accessed on 18/10/2017).

9. IPCC. 2013. Climate Change 2013: The Physical Science Basis Working Group I contribution to the IPCC 5th Assessment Report. Stockholm: Intergovernmental Panel on Climate Change.

10. IPCC. 2014. Climate Change 2014: Impacts, Adaptation, and Vulnerability. Part A: Global and Sectoral Aspects. Contribution of Working Group II to the Fifth Assessment Report of the Intergovernmental Panel on Climate Change. Cambridge, United Kingdom and New York, NY, USA: Cambridge University Press.

11. Isacs, L., Finnveden, G., Dahllöf, L., Håkansson, C., Petersson, L., Steen, B., Swanström, L., Wikström, A. 2016. Choosing a monetary value of greenhouse gases in assessment tools: A comprehensive review. Journal of Cleaner Production, Vol. 127, pp. 37-48. https://doi.org/10.1016/j.jclepro.2016.03.163

12. Jones, A.K., Jones, A.P., Cross, P. 2015. Developing farm-specific marginal abatement cost curves: Cost-effective greenhouse gas mitigation opportunities in sheep farming systems. Land Use Policy, Vol. 49 pp. $394-403$. https://doi.org/10.1016/j.landusepol.2015.08.006

13. Prandecki, K., Gajos, E., 2017. Ekonomiczna wycena emisji wybranych substancji do powietrza w Polsce ze szczególnym uwzględnieniem rolnictwa. Kwartalnik Naukowy Uczelni Vistula, Vol. 3(53). [In Polish]

14. Vermont, B., De Cara, S., 2010. How costly is mitigation of non-CO2 greenhouse gas emissions from agriculture? A meta-analysis. Ecological Economics, Vol. 69, pp. 1373-1386. https://doi.org/10.1016/j.ecolecon.2010.02.020

15. Yue, Q., Xu, X., Hillier, J., Cheng, K., Pan, G. 2017. Mitigating greenhouse gas emissions in agriculture: From farm production to food consumption. Journal of Cleaner Production, Vol. 149, pp. 1011-019. https://doi.org/10.1016/j.jclepro.2017.02.172 